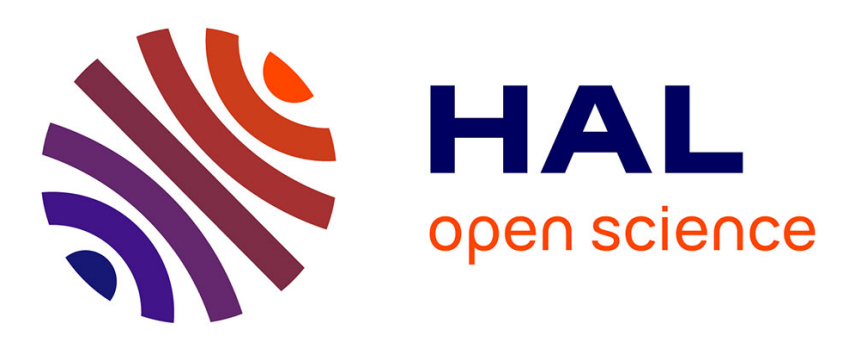

\title{
Chemical synthesis and crystal growth of AgGaGeS4, a material for mid-IR nonlinear laser applications
}

\author{
J. Rame, J. Petit, B. Viana
}

\section{To cite this version:}

J. Rame, J. Petit, B. Viana. Chemical synthesis and crystal growth of AgGaGeS4, a material for midIR nonlinear laser applications. 19th International Conference on Ternary and Multinary Compounds (ICTMC-19), Sep 2014, NIIGATA, Japan. hal-01087823

\section{HAL Id: hal-01087823 https://hal.science/hal-01087823}

Submitted on 26 Nov 2014

HAL is a multi-disciplinary open access archive for the deposit and dissemination of scientific research documents, whether they are published or not. The documents may come from teaching and research institutions in France or abroad, or from public or private research centers.
L'archive ouverte pluridisciplinaire HAL, est destinée au dépôt et à la diffusion de documents scientifiques de niveau recherche, publiés ou non, émanant des établissements d'enseignement et de recherche français ou étrangers, des laboratoires publics ou privés. 


\title{
Tue-O-11B
}

\section{Chemical synthesis and crystal growth of $\mathrm{AgGaGeS}_{4}$, a material for mid-IR nonlinear laser applications}

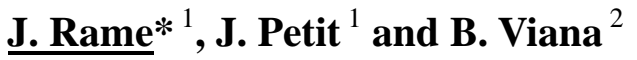 \\ ${ }^{1}$ ONERA, 29 avenue de la division Leclerc, 92322 Châtillon Cedex, France \\ ${ }^{2}$ IRCP Chimie ParisTech, 11 rue Pierre et Marie Curie, 75231 Paris Cedex 05, France \\ *e-mail : jeremy.rame@onera.fr
}

Mid infrared laser sources have attracted a particularly attention due to their potential applications in different fields such as infrared counter-measures and remote chemical sensing (e.g: LIDAR) [1]. Nowadays, there is a strong need for nonlinear materials able to convert efficiently a $1.064 \mu \mathrm{m}$ wavelength (Nd:YAG) to wavelengths higher than $4 \mu \mathrm{m}$. Consequently, we are particularly interested in the $\mathrm{AgGaGeS}_{4}$ compound (AGGS) which is a promising nonlinear material for mid-IR applications [2,3]. In the present work, the different steps of this material's processing will be described. The chemical synthesis of polycrystals and the single crystal growth process will be presented. Otherwise, we will discuss about the key parameters related to this material preparation and elaboration. Particularly, we will focus on compounds volatility which can induce stoichiometry deviation and reduce the quality of obtained single crystals. Currently, a $28 \mathrm{~mm}$ diameter and $70 \mathrm{~mm}$ length single crystals have been grown by the Bridgman-Stockbarger method, a cut and polished sample of AGGS crystal is presented on Fig 1. The crystal has good homogeneity and an absorption coefficient as low as $0.04 \mathrm{~cm}^{-1}$ in the $0.5-11.5 \mu \mathrm{m}$ range which make it usable in nonlinear optical devices. Difference frequency generation (DFG) experiments are currently in progress to characterize the nonlinear properties of the material.

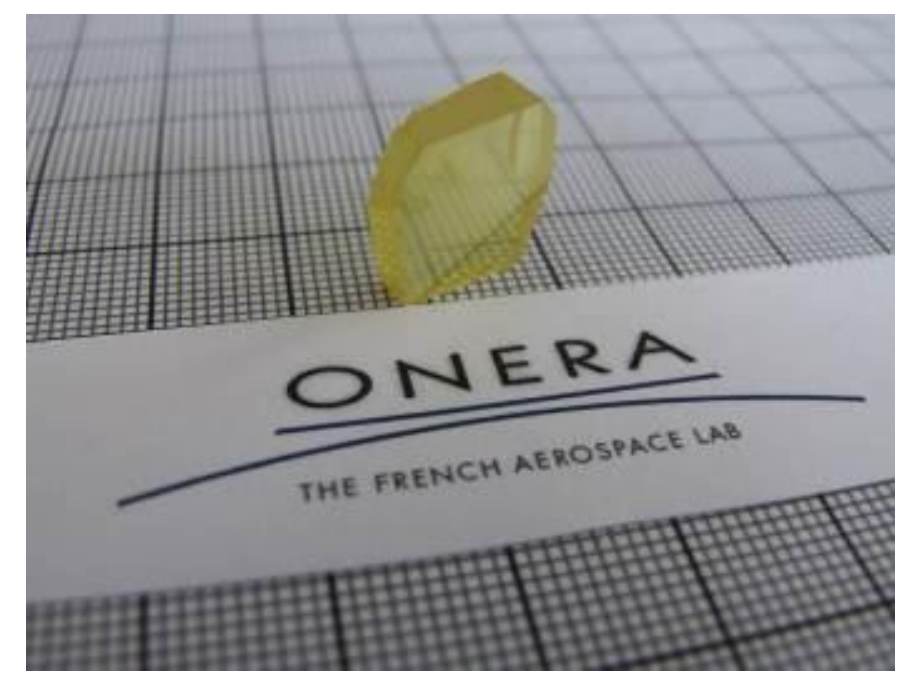

Fig. 1 Photograph of cut and polished $\mathrm{AgGaGeS}_{4}$ single crystal.

[1] V. Petrov, Opt. Mater. 34, 536-554 (2012).

[2] P.G. Schunemann, K.T. Zawilski and T.M. Pollak, J. Cryst. Growth 287, 248-251 (2006).

[3] V. Badikov, A. Tyulyupa, G. Shevyrdyaeva, S. Sheina, Inorg. Mater. 27, 177-180 (1991). 